\title{
「肺癌診療ガイドライン」の使用状況に関するアンケート集計結果
}

\author{
星川 康 $1,2 \cdot$ 桜田 晃1,2 ・ 佐渡 哲1,2 ・ 田畑俊治 $1,2 \cdot$ 遠藤千顕 $1,2 \cdot$ \\ 岡田克典 $1,2 \cdot$ 鈴木 聡 $1,2 \cdot$ 松村輔二 $1,2 \cdot$ 近藤 $\quad$ 丘 1,2
}

要旨一目的。「EBM の手法による肺癌診療ガイドライン 2003 年版」の使用状況およびこれに対する意見を調查す ることを目的とした。方法. 日本呼吸器外科学会認定施設, 関連施設, 日本肺癌学会員の在籍する施設, 530 施設を対 象にアンケート調查を行った . 結果 . 260 施設, 785 名の医師より回答を得た .回答者の $80 \%$ 以上が本ガイドラインの 使用経験があり，兰の半数以上が「診療方針決定」あるいは「インフォームドコンセント」といった実際の診療の場で の使用を目的としていた .回答者の約 $70 \%$ が本ガイドラインの出版により診療になんらかの影響があったと答えてお り，影響の種類の大部分は，「診療方針が決めやすくなった」あるいは「患者さんに説明しやすくなった」であった． 「今後記載されることか望ましい臨床的疑問点」あるいは「本ガイドラインへの要望」として，改訂への要請を含む多 数の有用な意見が寄せられた . 結論 . 本ガイドラインは多数の医師によって利用され , 肺癌診療に寄与していること が示唆された 一方で改訂への強い要請があることも明らかとなった，得られた多数の意見が今後のガイドライン改訂 に反影されるよう日本肺癌学会に要望したい. (肺癌 . 2005;45:319-328)

索引用語——肺癌診療ガイドライン, アンケート，改訂

\section{Questionnaire on Clinical Guidelines for the Management of Lung Cancer}

\author{
Yasushi Hoshi kawa1,2; Akira Sakurada1,2; Tetsu Sado1,2; Toshi haru Tabata1,2; Chi aki Endo1,2; \\ Yoshinori Okada1,2; Satoshi Suzuki 1,2; Yuji Matsumura1,2; Takashi Kondo1,2
}

\begin{abstract}
AB STRACT — Objective. With the support of the J apan Ministry of Health, Labor and Welfare, Clinical Guidelines for the Management of Lung Cancer were published in 2003. The objectives of this study are to assess how the guidelines have been used by surgeons and physicians and to survey their opinions on it. Methods. A questionnaire was designed and sent to 530 hospitals which were certified as training sites for chest surgeons by the Japanese Association for Chest Surgery or which have members of the J apan Lung Cancer Society on their staff. R esults. A total of 785 doctors in 260 hospitals answered the questionnaire. More than $80 \%$ of the participants had used the guidelines. In more than half, the purpose for using them was for choosing the treatment or for informed consent. Approximately $70 \%$ of the participants answered that the guidelines had an influence on their practice, most of which was making their clinical decisions and explanation to their patients easier. The participants gave us many useful opinions including requests for revision. Conclusion. This study revealed that the guidelines were utilized by many surgeons and physicians. It also indicated that the publication of the guidelines contributed to their management of lung cancer. There were many suggestions for the guidelines which should be helpful for its revision currently conducted by the Japan Lung Cancer Society. (J) LC. 2005;45:319-328)

\footnotetext{
1東北大学加齢医学研究所呼吸器再建研究分野,2東北大学病院呼 吸器外科.

別刷請求先: 星川 康, 東北大学加齢医学研究所呼吸器再建研究 分野, 干 980-8575 宮城県仙台市青葉区星陵町 4-1 (e-mail: yasuhosh@idac.tohoku.ac.jp) .

1Department of Thoracic Surgery, Institute of Development, Aging, and Cancer, Tohoku University, Japan; 2Department of Tho-
}

racic Surgery, Tohoku University Hospital, J apan.

Reprints: Yasushi Hoshikawa, Department of Thoracic Surgery, Institute of Development, Aging, and Cancer, Tohoku University, 4-1 Seiryo-cho, Aoba-ku, Sendai 980-8575, Japan (e-mail: yasuhosh @idac.tohoku.ac.jp).

Received March 31, 2005; accepted May 24, 2005.

(C) 2005 The J apan Lung Cancer Society
\end{abstract}


はじめに

平成 13～14 年度厚生労働省医療技術評価研究事業に より策定された「肺癌診療ガイドライン」が平成 15 年 10 月 25 日金原出版株式会社より「EBM の手法による肺癌
診療ガイドライン 2003 年版」として発行された . 1 今回 ， このガイドラインの使用状況およびこれに対する意見を 調査する目的で, 肺癌の診療にあたっている医師を対象 にアンケートを発送し ,260 施設 ,785 名の医師より回答 を得た . アンケートの集計結果を報告する .

表 1. 肺癌の診療ガイドラインの使用状況に関するアンケートと各質問に対する回答率

本アンケートは, 肺癌の診療にあたっている医師を対象に,「EBM の手法による肺癌診療ガイドライン」(金 原出版)の使用状況および炎れに対する御意見を調査する目的で行われるものです。こ協力をお願い致します。

A.あなたの専門をお答え下さい（回答率 99.9\%)

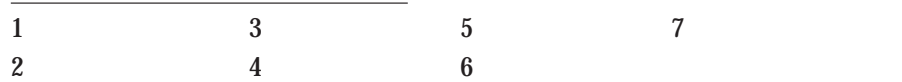

B. 医師としての経験年数をお答え下さい (回答率 100\%)

1. 研修医 2.10 年末満 3.20 年末満 4.20 年以上

C.どの程度ガイドラインを使用しましたか (回答率 98\%)

1. 使用せず 2.3 回以内 3.4-9 回 4.10 回以上

D .ガイドラインの使用目的をお答え下さい (複数可) (回答率 88\%)

1. 患者の診療方針を決定するため 4. 文献情報を得るため

2. インフォームドコンセント 5. 弚の他

3. 知識の整理

E．あなたが参考にした章をお答え下さい(複数可) (回答率 85\%)

1. 肺癌の診断 8. 非小細胞肺癌 Stage I 期

2. 肺癌の化学療法 9. 非小細胞肺癌 Stage II 期

3. 肺癌の放射線治療 10 . 非小細胞肺癌 Stage III 期

4. 肺癌の手術療法 11 . 非小細胞肺癌 Stage IV 期

5. 肺癌の術前術後併用療法 12 . 小細胞肺癌 Stage I 期

6. 中心型早期肺癌の診断 · 治療 13 . 限局型小細胞肺癌

7. 肺癌の胸腔鏡手術 14 . 進展型小細胞肺癌

F.ガイドラインを患者に適用できましたか？（回答率 85\%)

1. 適用できた 2. 部分的に適用できた 3 . 適用できなかった

F-I . 特に参考になった項目がありましたらお答え下さい (回答率 5\%)

F-II .ガイドラインが適用できなかった場合, 兴の原因についてお答え下さい (症例の臨床的な状況を簡単 に述べて頂いても結構です) （回答率 11\%)

G．今後記載されることが望ましい臨床的疑問点がありましたら，具体的に記載してください (回答率 9\%)

H．ガイドラインの出版によってあなたの診療に影響がありましたか? (回答率 85\%)

1. 大きく影響を受けた 2. 多少の影響を受けた 3. 全く影響がない

H-I . 影響があった場合，どのようなものですか (複数可) (回答率 77\%)

1. 診療方針が決めやすくなった 4 . 患者さんへの説明事項が増えた

2. 患者さんに説明しやすくなった 5. 产の他（

3. 診療方法を変える必要が生じた

I. 診療の参考にされているガイドラインあるいはデータベースをお答え下さい (回答率 93\%)

1. 本ガイドライン

2. Cochrane Library

4. Medline, PubMedなどで独自に検索

3. 兴の他 (

5. 特になし

」.ガイドラインに関する御意見を自由に御記入下さい (回答率 13\%) 
対象と方法

平成 16 年 9 月 17 日 ,「肺癌診療ガイドライン」に対す るアンケート (表 1)を, 日本呼吸器外科学会認定施設, 関連施設, 日本肺癌学会員の在籍する施設, 530 施設に, 各施設 5 枚ずつ,合計 2650 枚発送した .平成 16 年 11 月 15 日までに返送された回答に関して集計作業を行った .

各質問項目に対する回答者の比率の検定にはカイ 2 乗 検定を用い， $p<0.05$ を有意とした .

結 果

アンケートを発送した 530 施設中 260 施設 $(49 \%$ ) ,785 名の医師より回答を得た .

各質問項目に対する回答率を表 1 に示す．

A . 回答者の専門領域 (図 1)

アンケートに回答した医師の専門領域（科）は，呼吸 器外科 556 名 $(71 \%)$, 呼吸器内科 165 名 $(21 \%)$, 一般 外科 26 名 (3\%)，放射線科 18 名 $(2 \%)$, 腫瘍内科 4 名 (1\%), 光の他 16 名 (2\%) であった (図 1$)$.

B . 回答者の医師としての経験年数 (図 2)

アンケートに対する回答者の医師としての経験年数 は, 20 年以上が 227 名 $(29 \%), 10$ 年以上 20 年末満が 329 名 ( $42 \%)$ ，初期研修終了後〜10 年未満が 213 名 ( $27 \%)$, 初期研修中が 16 名（2％) であった（図 2).

C . ガイドラインの使用回数 (図 3)

回答者の約 $1 / 4$ が 10 回以上, 半数以上が 4 回以上, $80 \%$ 以上が最低 1 回は本ガイドラインを使用していた 科別では, 肺癌診療の機会が多いと考えられる呼吸器内 科, 呼吸器外科において, 光れ以外の科に比し使用回数 が多い傾向がみられたが統計学的な有意差を認めなかっ た(図 3A). 経験年数別では, 研修医において研修後〜10 年末満, 10 年以上 20 年未満に比し使用回数が有意に少 なかった $(p<0.05)$. 研修後 10 年末満，10 年以上 20 年末満， 20 年以上の間に明らかな差を認めなかった (図 3B) .

D . ガイドラインの使用目的 (複数回答可) (図 4)

本ガイドラインの使用目的として，全体では「知識の 整理」(34.9\%) が最も多く，次いで「診療方針決定」

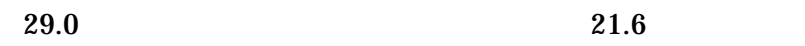
情報入手」(13.3\%)，「炎の他」(1.2\%) の順であった（図 4A ). 光の他の欄の記載内容は, 学生講義の資料, 試験問 題作成の際の資料として (3 名)，研修医の指導，勉強会 (2 名)，講演会での使用 (1 名)，論文作成の際の資料と して (1名)，等であった (図 4A).

科別の集計では，一般外科あるいは光の他の科の回答 者において「診療方針決定」を目的にガイドラインが使 用される頻度が高い傾向を認めた(図 4A) . 腫瘍内科を専

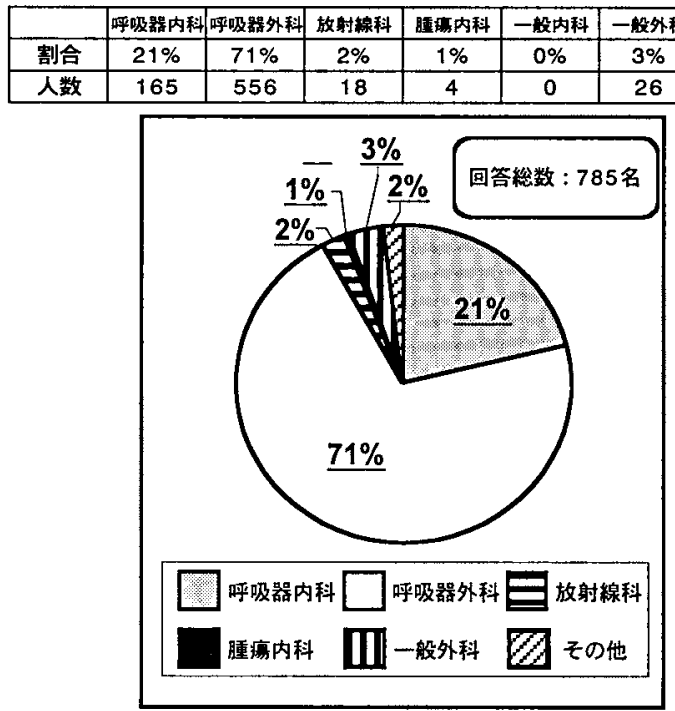

図 1. A.アンケートへの回答者の専門領域 (科) .

\begin{tabular}{|c|c|c|c|c|}
\hline & 研修医 & 10 年末満 & 20 年未満 & 20 年以上 \\
\hline 割合 & $2 \%$ & $27 \%$ & $42 \%$ & $29 \%$ \\
\hline 人数 & 16 & 213 & 329 & 227 \\
\hline
\end{tabular}
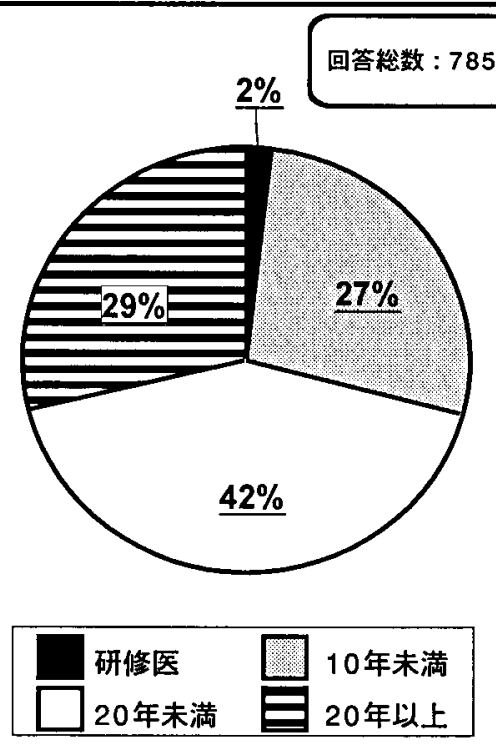

図 2. B. アンケートへの回答者の医師としての経験年数 .

門とする回答者においては，「知識の整理」を目的に使用 したとの回答が多く、「診療方針決定」を目的に使用した との回答はなかった(図 4A). 呼吸器内科, 呼吸器外科, 放射線科では使用目的頻度に明らかな差を認めなかった (図 4A).

経験年数別では, 使用目的の頻度に明らかな差を認め 
A

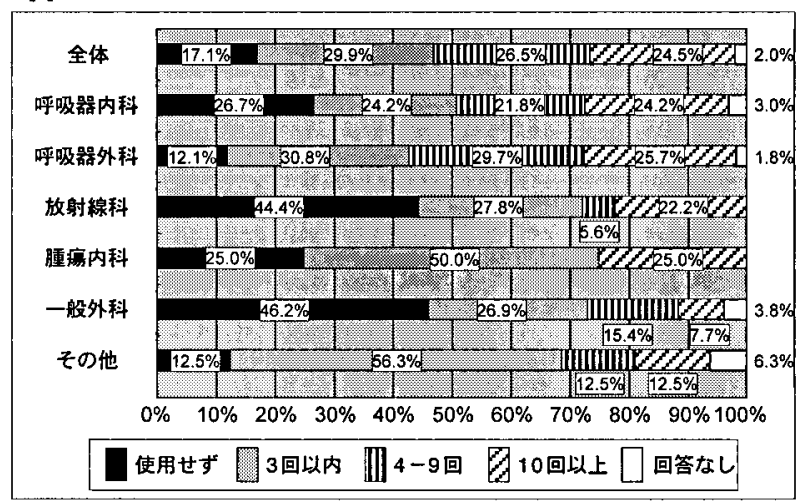

B

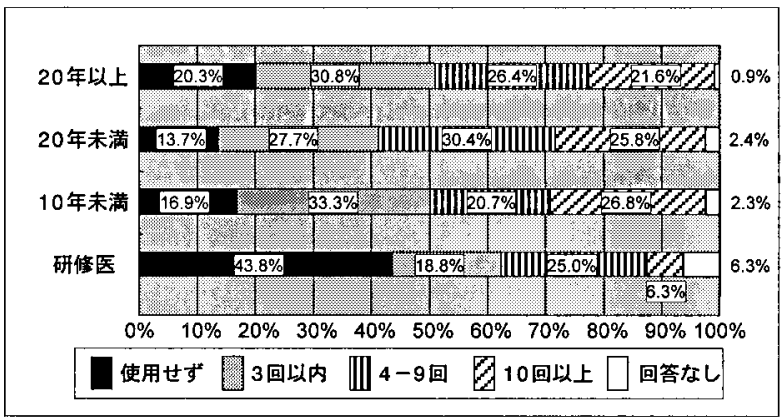

図 3.C. ガイドラインの使用回数 (A. 科別 , B . 経験年数 別).
A

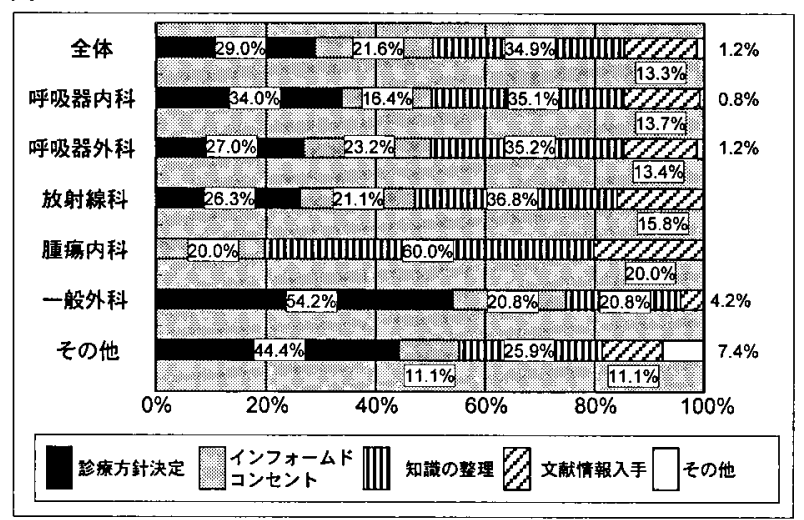

B

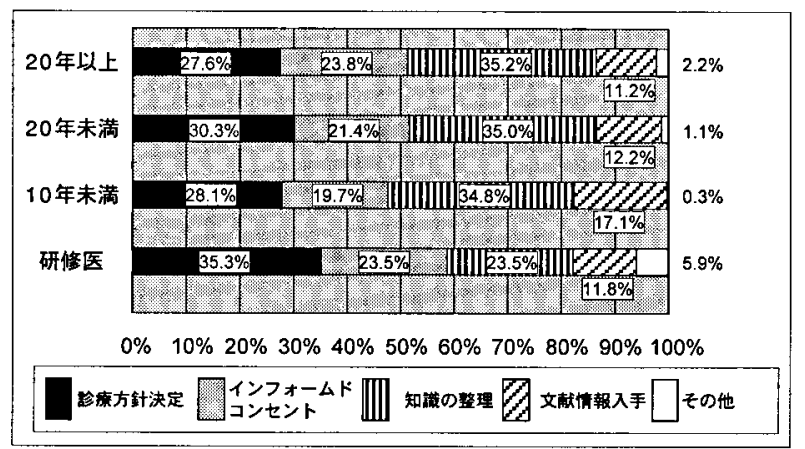

図 4. D. ガイドラインの使用目的 (A . 科別，B . 経験年数 別).

表 2. E . 参考にした章

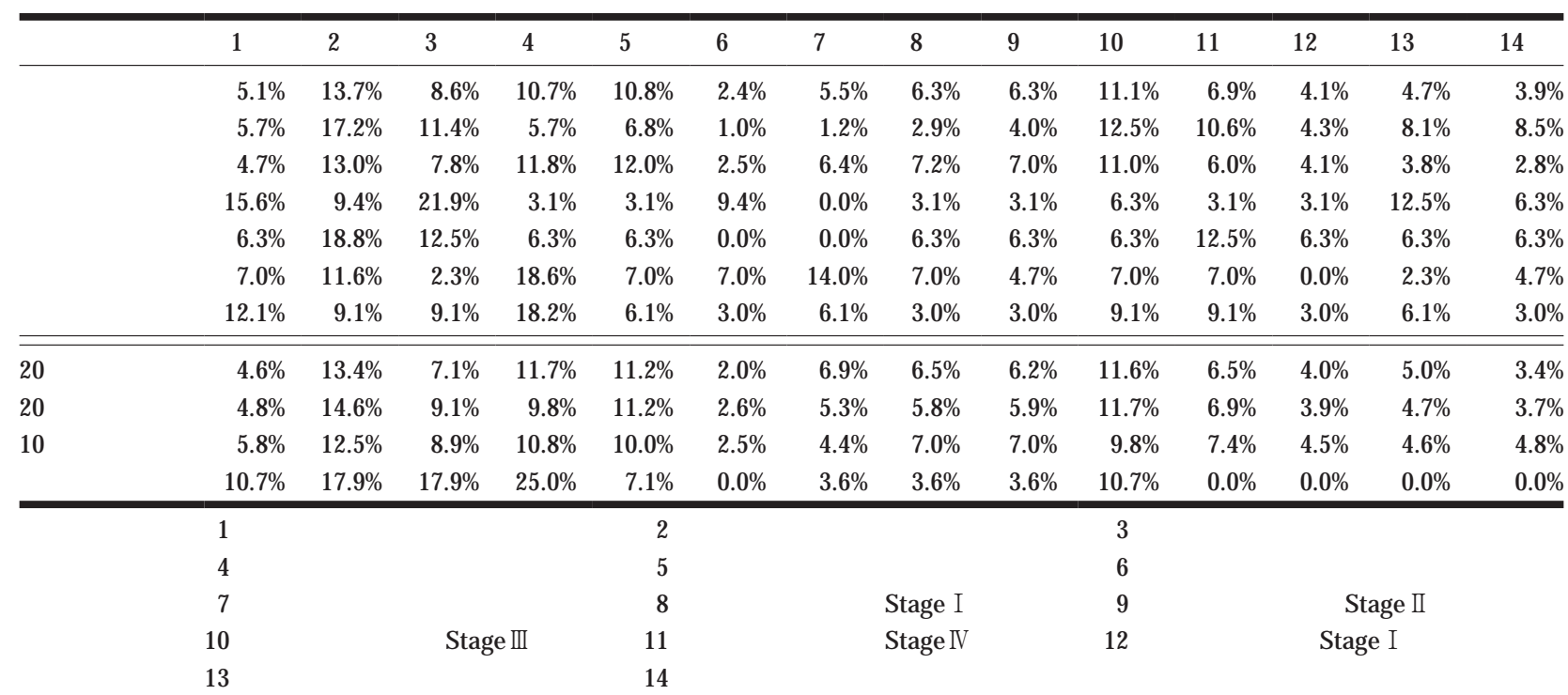

なかった（図 4B) .

E . 参考にした章 (複数回答可) (表 2)

参考にした章に関しては，科ごとの特性（放射線科で は第 7 章 . 肺癌の胸腔鏡手術, 腫瘍内科では第 6 章 .中
心型肺癌の診断・治療，第 7 章，一般外科では第 12 章 . 小細胞肺癌 Stage I 期が , 使用されていない)はあるもの の, 全体的には全ての章が使用されていることがわかる (表 2). 
A

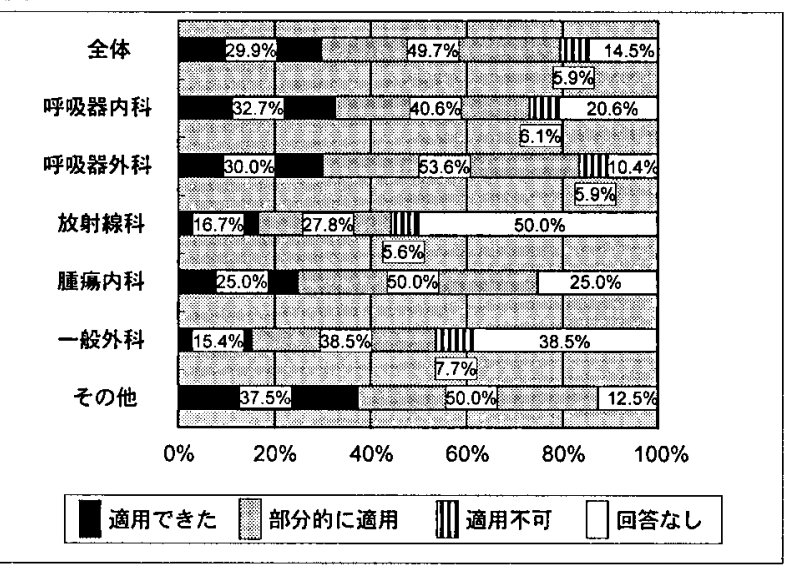

B

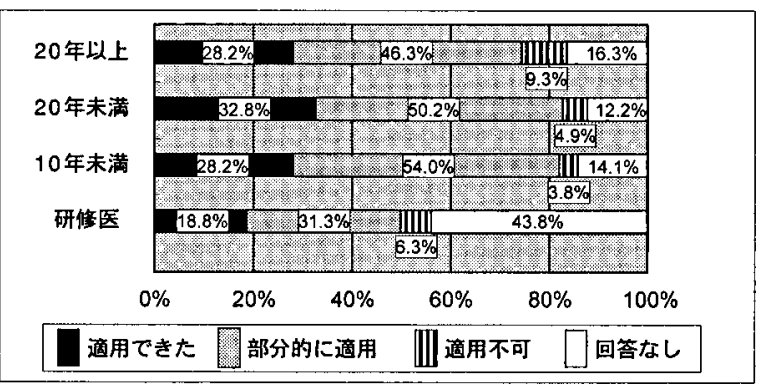

图 5.F．ガイドラインの患者への適用度 (A．科別，B．経 験年数別).

表 3. F-I．特に参考になった項目

\begin{tabular}{|c|c|}
\hline 記載内容 & 人数 \\
\hline - 化学療法 & 8 \\
\hline · 術前術後療法 & 8 \\
\hline - Stage 別治療法 & 6 \\
\hline ·全体的に (文献，evidence の確認，知識の整理) & 5 \\
\hline 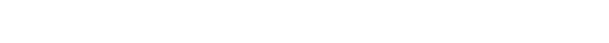 & 4 \\
\hline ·手術療法 & 4 \\
\hline • 胸腔鏡手術 & 2 \\
\hline •限局型小細胞肺癌 & 2 \\
\hline • 再発非小細胞肺癌の治療 & 2 \\
\hline 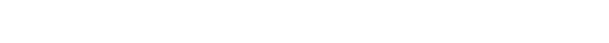 & 1 \\
\hline ·進展型小細胞肺癌 & 1 \\
\hline · N2 に対する化学放射線療法 & 1 \\
\hline - cT4N0-1 の非小細胞肺癌の手術適応について & 1 \\
\hline •標準的治療について & 1 \\
\hline • 小細胞肺癌に対する PCI の評価の記事 & 1 \\
\hline
\end{tabular}

経験年数別では，研修医では第 6 章（中心型肺癌の診 断・治療)，11１4 章(非小細胞肺癌 Stage IV 期，小細胞 肺癌 Stage I 期, 限局型小細胞肺癌, 進展型小細胞肺癌) が使用されていないが, 研修後〜 10 年未満, 10 年以上 20
A

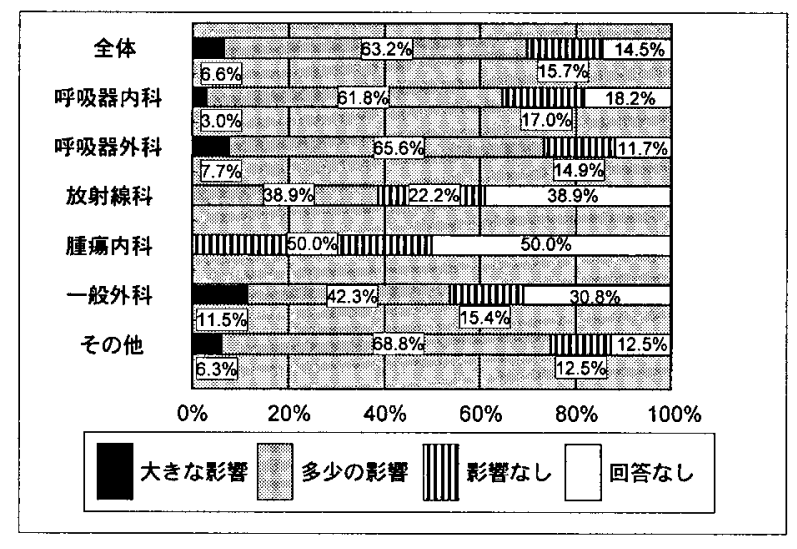

B

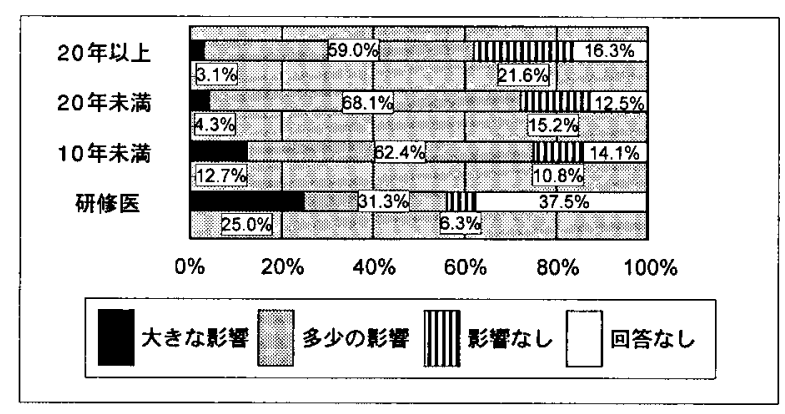

図 6. H. ガイドラインの出版による診療への影響の有無 (A. 科別，B. 経験年数別).

表 4.F-II . ガイドラインが患者に適用できなかった原因

\begin{tabular}{|c|c|}
\hline 記載内容 & 人数 \\
\hline •ガイドラインの内容 (データや療法) の遅れ & 15 \\
\hline •患者あるいは家族の希望 & 14 \\
\hline ·年齢 & 11 \\
\hline ·合併症 & 9 \\
\hline •患者の体力 , PS & 8 \\
\hline ·具体性に欠ける記載 & 8 \\
\hline $\begin{array}{l}\text { •記載が無いあるいは不足している (癌性胸膜炎に対 } \\
\text { する化学療法, 小細胞の発, 小型肺癌に対する縮 } \\
\text { 小手術, 発肺癌に対する治療) }\end{array}$ & 5 \\
\hline •参考のために使用 & 4 \\
\hline ・ガイドラインの存在が，あまり念頭にない & 4 \\
\hline • evidence のグレードが低い場合 & 4 \\
\hline •施設間の差 (設備 , 指針) & 4 \\
\hline ・化学療法のレジメがいくつもあり, 選択しづらい & 1 \\
\hline$\cdot$ advanced NSCLC (trial case) & 1 \\
\hline •日本人に光のまま適応できないこともあった (用量) & 1 \\
\hline
\end{tabular}

年末満, 20 年以上では全ての章が使用されており, 明ら かな傾向の差を認めなかった (表 2).

F . ガイドラインの患者への適用度 (図 5) 全体的には , 回答者の $29.9 \%$ が , 本ガイドラインを患 
表 5. G . 今後記載されることか望ましい臨床的疑問点として記載された事項

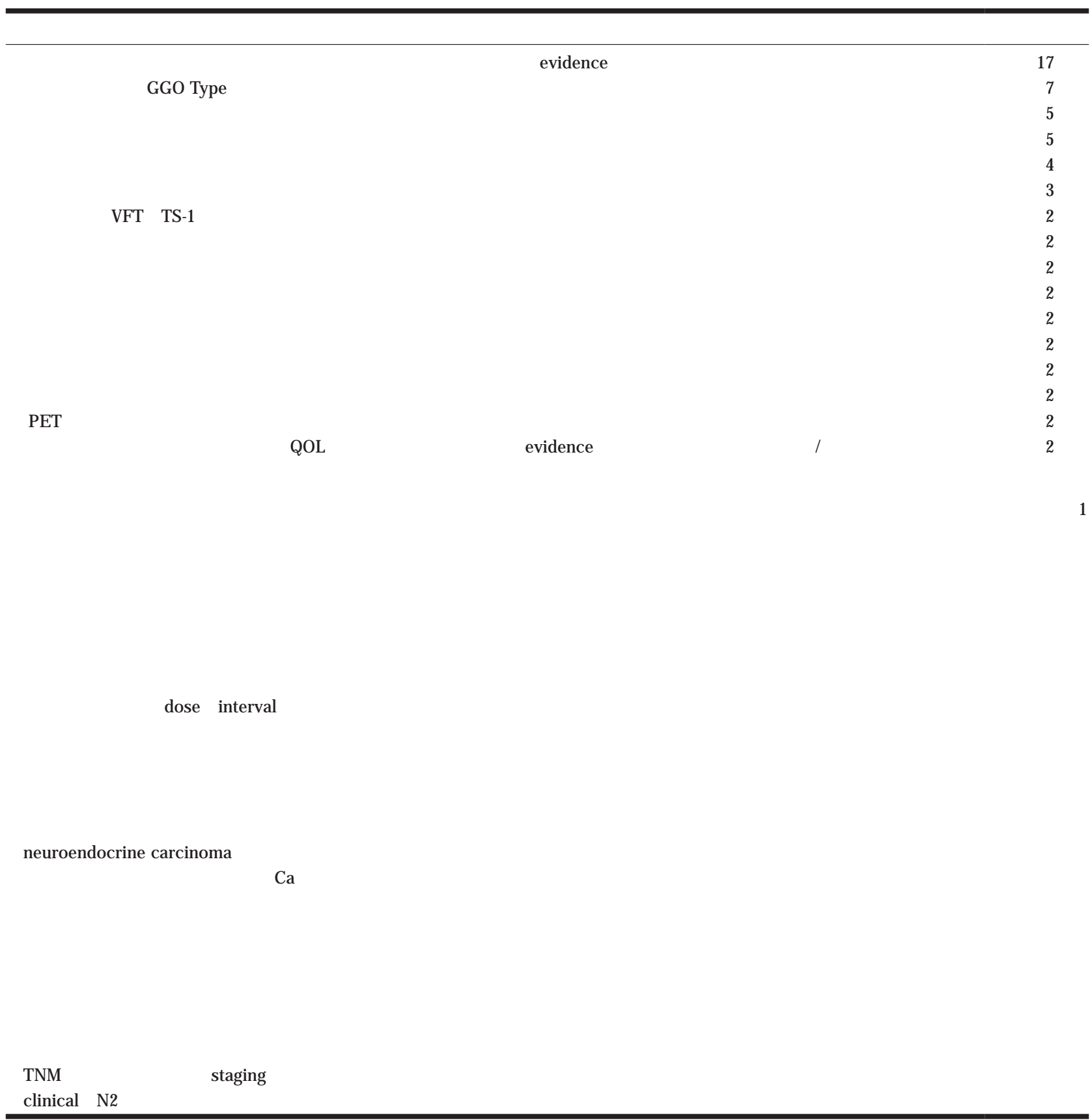

者に「適用できた」，49.7\% が「部分的に適用できた」と 答えている(図 $5 A$ ) . 科別では, 放射線科および一般外科 で，「回答なし」が多かった (図 5A) . 経験年数別では， 研修医で「回答なし」が多かった（図 5B）．研修後～10 年末満, 10 年以上 20 年末満, 20 年以上では , 経験年数 が多くなるほど「適用不可」と回答する頻度が増加する 傾向がみられた（図 5B）.

F-I. 特に参考になった項目 (表 3)

特に参考になった項目として記載が多かったのは，「化
学療法」(8 名), 「術前術後療法」(8 名), 「Stage 別治療 法」(6名)であつた（表 3)．

F-II .ガイドラインが患者に適用できなかった原因 (表 4) 質問 F. のガイドラインが患者に適用できなかった原 因として 「ガイドラインの内容(データや療法)の遅れ」 (15 名)，「患者あるいは家族の希望」(14 名 )，「年齢」(11 名)，「合併症」(9名)，「患者の体力, PS (performance status $)\lrcorner(8$ 名 $)\ulcorner$ 具体性に欠ける記載」(8 名) 等といった ことの記載頻度が高かった（表 4 ）。 
A

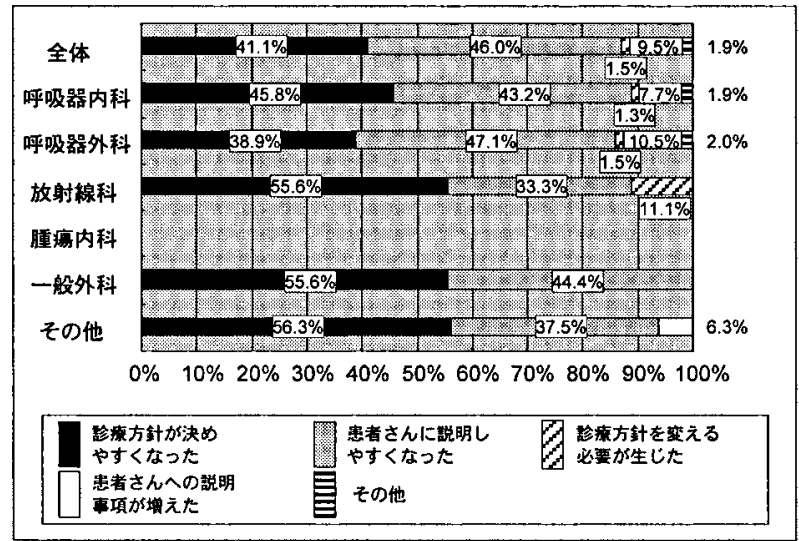

B

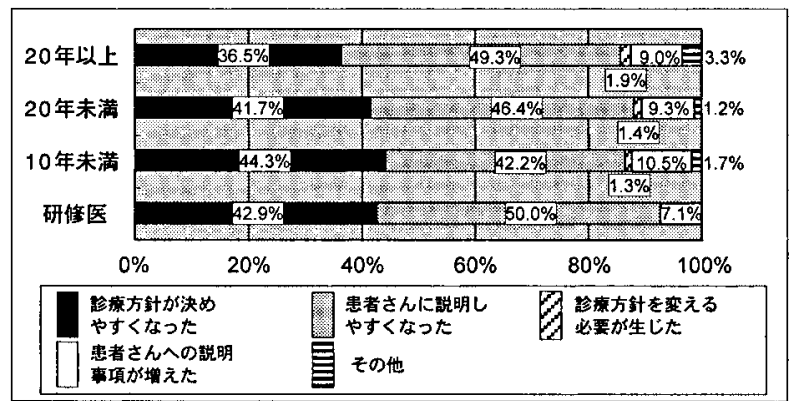

図 7.H-I.ガイドラインの出版による診療への影響の種類 (A. 科別，B. 経験年数別).

G．今後記載されることが望ましい臨床的疑問点(表 5)

今後記載されることか望ましい臨床的疑問点として記 載の多かったのは, 「術後補助化学療法」(17 名)，「末梢小 型結節・GGO (ground glass opacity) Type の肺癌の診 断・治療方針」(7 名)，「術後再発例・転移例に対する治 療法」(5 名)，「転移性肺腫瘍の治療方針・手術適応」( 5 名)であった (表 5) . この他にも多数の貴重な意見が寄 せられた(表 5) .

H . ガイドラインの出版による診療への影響 (図 6)

回答者の $6.6 \%$ が , 本ガイドラインの出版により診療 に「大きな影響」があったと答えている．同樣に $63.2 \%$ が「多少の影響があった」としている．反対に $15.7 \%$ の 回答者が「影響なし」と答えている (図 6A) . 科別では， 放射線科では「大きな影響」があったとの回答はなかっ た (図 6A).腫痬内科では「影響なし」と「回答なし」が 半々であった(図 6A). 経験年数別では, 年数が少ない程 「大きな影響」があったとする回答の割合が大きい傾向を 認めた (図 6B) . 反対に年数が多い程「影響なし」とする 割合が大きい傾向を認めた (図 6B).

H-I. 影響の種類 (複数回答可) (图 7)

本ガイドラインの診療への影響の種類の大部分は「診 療方針が決めやすくなった」あるいは「患者さんに説明

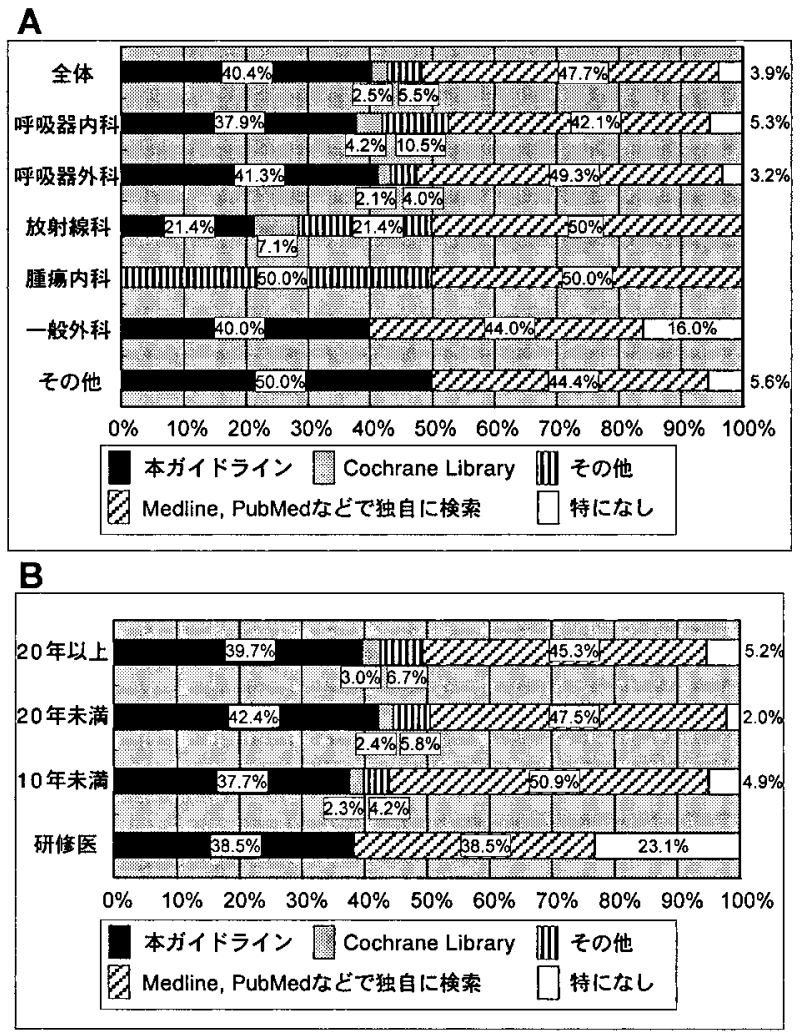

図 8. I. 診療の参考にしているガイドラインあるいはデー タベース (A. 科別，B. 経験年数別).

しやすくなった」であった (図 7) .

ぞの他の欄の記載は, 「自分の知識の整理・確認に役 立った」4 名，「医師への説明が少なくなった」1名，「研修 医の教育」1名，「学生講義に EBM を示すことができる」 1 名であった。

I . 診療の参考にしているガイドラインあるいは

データベース (図 8)

診療の参考にしているガイドライン・データベース は，全体では「Medline，PubMedなどで独自に検索」 $47.7 \%$ ，「本ガイドライン」40.4\%，「Cochrane Library」 $2.5 \%$ ，光の他 $5.5 \%$ であった(図 $8 \mathrm{~A}$ ). 光の他の欄には， ASCO 11 名, Up To Date 8 名, NCCN 4 名, 医中誌 2 名,

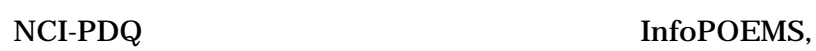
ACCP ガイドライン ,AHRQ 報告の他, 独自のガイドライ ン 4 名, 自院データ 2 名といった記載もみられた .

科別では，本ガイドラインを診療の参考にしていると の回答は, 腫瘍内科ではみられず, 放射線科でも他の科 に比し光の頻度が少ない傾向を認めた（図 8A）。

経験年数別では，研修医で「Cochrane Library」,「炎の 他」がみられないものの, 弚の他明らかな傾向の差を認 めなかった (図 8B). 
表6. 」 . 本ガイドラインに対する意見

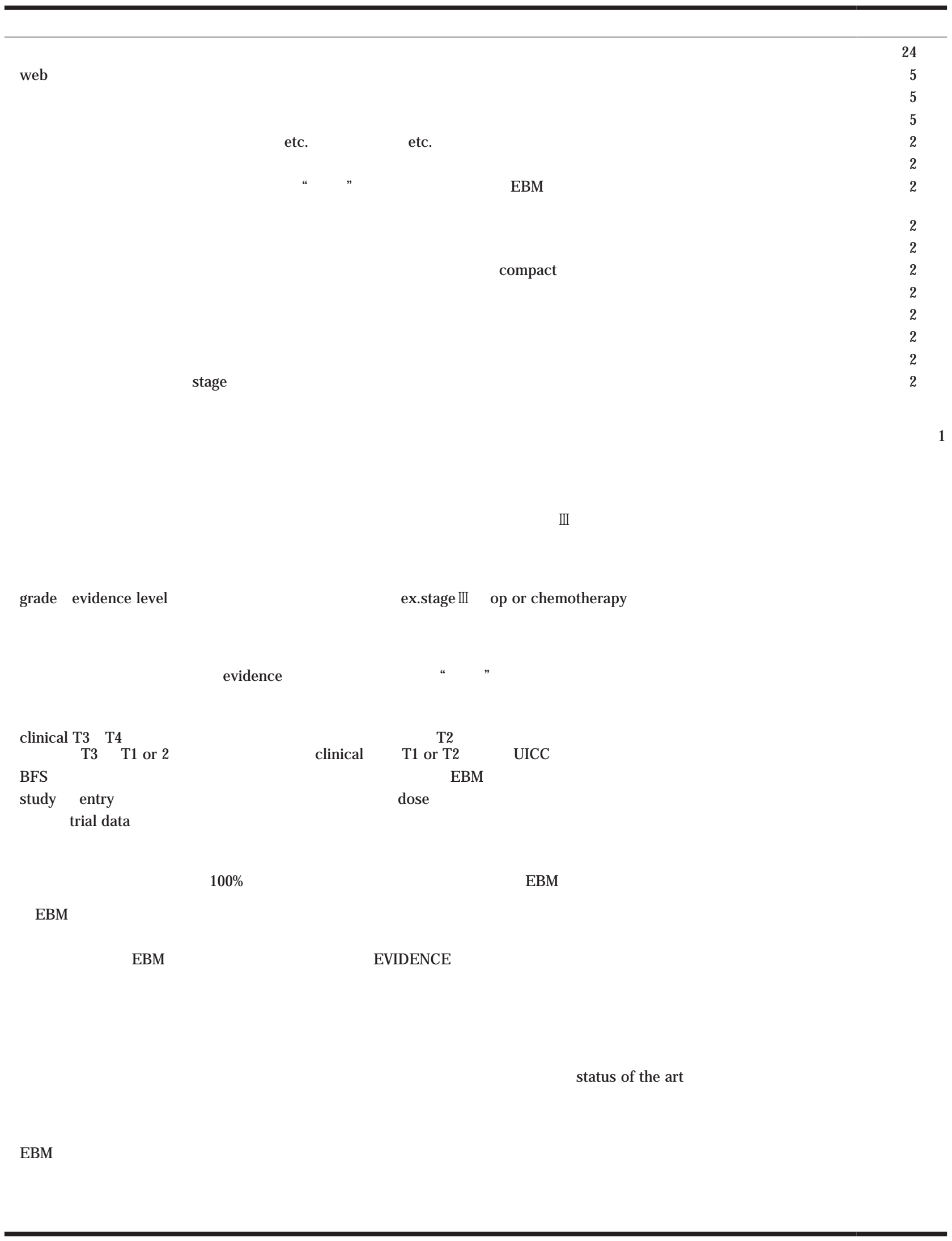


表6. J . 本ガイドラインに対する意見 (つづき)

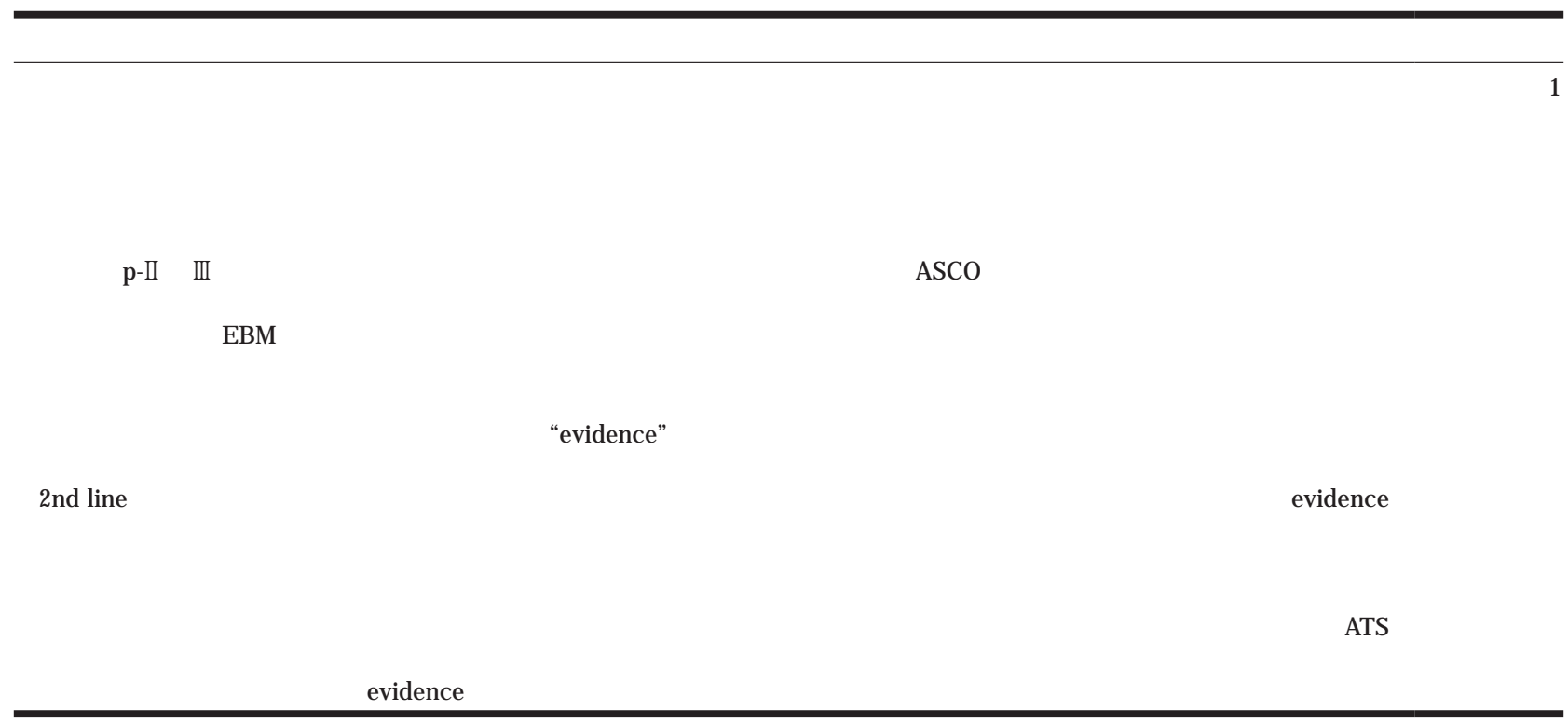

J.ガイドラインに対する意見 (表 6)

本ガイドラインに対する意見として自由記載とした部 分への記載で多かったものは，「(定期的な)改訂が必要」 (24名)，「webでも見ることができるようにしてほし い」(5 名)であった . 炎の他，多数貴重な意見が寄せられ た (表6).

\section{考 察}

アンケートを発送した 530 施設中，約半数の 260 施設 785 名もの医師より回答を得た . 回答者の $71 \%$ の専門領 域が呼吸器外科であった．これは，アンケート発送先を 日本呼吸器外科学会認定施設, 関連施設, 日本肺癌学会 員の在籍する施設のうち前記 2 者以外の施設としたため であると考える. 集計結果全体の傾向が呼吸器外科医の 意見に偏ってしまった可能性は否定できない.このため 科別の集計結果も併記した .

ガイドラインの使用回数に関しては, 回答者 785 名中 約 $1 / 4$ が 10 回以上,半数以上が 4 回以上, $80 \%$ 以上が最 低 1 回は使用したと回答している . 今回のアンケート調 査により, 本ガイドラインが発行から 1 年の間に多数の 医師に使用されていることが明らかとなった .

使用目的としては，「診療方針決定」あるいは「イン フォームドコンセント」といった実際の診療が半数以上 を占めた . 参考にした章に関しては，科ごとの特性はあ るものの, 全体的には全ての章が使用されていた . ガイ ドラインの患者への適用度は,全体の約 $80 \%$ の回答者が 「適用できた」あるいは「部分的に適用できた」と答えて いる．反対に $5.9 \% ， 46$ 名の回答者が「適用できなかっ
た」と答えている . その原因として「ガイドラインの内 容 (データや療法) の遅れ」,「年齢」,「合併症」,「患者 の体力, PS (performance status)」，「具体性に欠ける記 載」等が挙げられており, 今後の改訂の際の課題と考え られる.

回答者の約 $70 \%$ が 本ガイドラインの出版により診療 に「多少の影響」あるいは「大きな影響」があったと答 えている.影響の種類の大部分は,「診療方針が決めやす くなった」あるいは「患者さんに説明しやすくなった」 であった .この結果は, 本ガイドラインが肺癌の実地診 療に寄与していることを示すものである .

今後記載されることが望ましい臨床的疑問点として， 多数の意見が寄せられた このうち「術後補助化学療法」, $\ulcorner$ 定位照射療法」, 「PET」に関しては, 現在改訂作業が進 行中の新版で新たな記載がなされる予定である「末梢小 型結節・GGO (ground glass opacity) Type の肺癌の診 断・治療方針」に関しては，一部本ガイドラインにも記 載されており，また現在進行中の改訂作業でも検討がな されているが, エビデンスレベルの高い論文が極めて少 ないのか現状である . 今後の改訂にあたってひきつづき 検討されるべき臨床的疑問点であろう「術後再発例・転 移例に対する治療法」,「転移性肺腫瘍の治療方針・手術 適応」,「高齢者，合併症を有する患者に対する治療法」， $「$ 術後合併症と光の治療法」「悪性胸膜中皮腫に対する治 療法」,「セカンドラインの治療法」,「傍腫瘍症候群 (癌 性胸膜炎, 高 Ca 血症など) に対する治療法」等は, 今後 の改訂の際に是非検討されるべき臨床的疑問点であると 考える. 
本ガイドラインに対する意見として自由記載とした中 で最も多かった「(定期的な) 改訂」に関しては，日本肺 癌学会において改訂頻度の検討がなされている．また， 「web でも見ることができるようにしてほしい」という 意見も多数みられた . 本ガイドラインは, 日本医療機能 評価機構のMinds (Medical Information Network Distribution Service) 医療情報サービス (http://minds.jcqhc. or.jp/to/index.aspx) で既にweb 上に公開されている.多 くの医師の利用を希望する．一般外科の先生から「胃癌 のガイドラインの方が使いやすい」という意見が 2 件寄 せられている . 他領域のガイドラインのあり樣を参考に することも重要であろう .

まとめ

今回のアンケート調査により, 本ガイドラインが多数 の医師により利用されていることが明らかとなり，肺癌 診療に寄与している可能性が示された . 一方で, 定期的 な改訂, 記載事項のさらなる充実を求める声が非常に多
いことも明らかとなった . 得られた貴重な意見が, 現在 進行中の改訂のみならず, 次回以降の改訂にも反影され るよう日本肺癌学会に要望したい.

謝辞 : 稿を終えるにあたり，アンケート調査に御協力下さつ た先生方に御礼申し上げます.また，アンケート発送・集計・ 図表作成を行って下さいました小山田悟子さんに深謝致しま す.

本研究は, 平成 16 年度厚生労働科学研究費補助金 (医療技 術評価総合研究事業), 「電子化に向けた肺癌診療ガイドライ ンの整備(H16 - 医療 -062 , 研究代表者 : 近藤丘)」によった .

\section{REFERENCE}

1.EBM の手法による肺癌診療ガイドライン Evidencebased Medicine(EBM)の手法による肺癌の診療ガイドラ イン策定に関する研究班 編集 東京:金原出版;2003. 